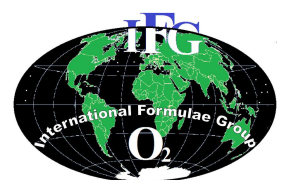

Available online at http://ajol.info/index.php/ijbcs

Int. J. Biol. Chem. Sci. 9(2): 1004-1012, April 2015

International Joumal

of Biological and

Chemical Sciences

ISSN 1997-342X (Online), ISSN 1991-8631 (Print)

Original Paper

http://indexmedicus.afro.who.int

\title{
Effects of Alium cepa Linn on rhodanese activities and half-life of cyanide in the blood
}

\author{
Fausat Kikelomo OLA-MUDATHIR ${ }^{1,2^{*}}$ and Emmanuel N. MADUAGWU ${ }^{1}$ \\ ${ }^{1}$ Department of Biochemistry, University of Ibadan, Ibadan, Nigeria. \\ ${ }^{2}$ Department of Chemical Science, Crescent University, Abeokuta, Nigeria. \\ *Corresponding author; E-mail: fausatkike@yahoo.co.uk; Tel: +2348052248092
}

\begin{abstract}
Rhodanese is the major detoxifying enzyme for cyanide and requires sulphur for its action. Allium cepa (Onion) is rich in organosulphur which may serve as an antidote for cyanide poisoning by supplying sulphur to the enzyme rhodanese. The possible effects of Allium cepa on rhodanese activity during cyanide toxicity was investigated in male Wistar rats. Sixty Wistar rats (150-180 g) were divided into ten groups of six rats each. The first six groups were used for in vivo rhodanese activities evaluation after treatments orally with either $\mathrm{KCN}(7 \mathrm{mg} / \mathrm{kg}$ bwt/day $\mathrm{KCN}), \mathrm{KCN}+300 \mathrm{mg}$ Methanol Extract of Allium cepa (MEAC)/kg bwt/day, $\mathrm{KCN}+600 \mathrm{mg} \mathrm{MEAC/kg} \mathrm{bwt/day,} \mathrm{KCN}+600 \mathrm{mg}$ sodium thiosulphate $\left(\mathrm{Na}_{2} \mathrm{~S}_{2} \mathrm{O}_{3}\right) / \mathrm{kg}$ bwt/day or $600 \mathrm{mg}$ $\mathrm{MEAC} / \mathrm{kg}$ bwt/day respectively. The last four groups were used for the evaluation of half-life of $\mathrm{KCN}$ after treatment orally with distilled water (control), $600 \mathrm{mg} \mathrm{MEAC/kg} \mathrm{bwt/day,} 600 \mathrm{mg} \mathrm{Na} \mathrm{S}_{2} \mathrm{O}_{3} / \mathrm{kg}$ bwt/day and raw onion adlibitum respectively for two weeks before intravenous injection of KCN. In vitro rhodanese activity was determined using liver homogenate. Results of the in vivo study showed liver rhodanese activity was significantly higher $(\mathrm{p}<0.05)$ in the cyanide only group and in the cyanide $+\mathrm{Na}_{2} \mathrm{~S}_{2} \mathrm{O}_{3}$ group when compared with the control group, but administration of MEAC in the cyanide treated group did not enhance the activities of rhodanese. The results of the in vitro study showed that rhodanese activity was more enhanced in the presence of essential oil of onion and $\mathrm{Na} \mathrm{S}_{2} \mathrm{O}_{3}$. The half-life of $\mathrm{KCN}$ was significantly lower $(\mathrm{p}<0.05)$ with consumption of raw onion when compared with control. The results suggest that Allium cepa enhance cyanide detoxification by enhancing rhodanese enzyme activities. This effect is more pronounced with the essential oil of onion.

(C) 2015 International Formulae Group. All rights reserved.
\end{abstract}

Keywords: Cyanide, rhodanese, onion, half-life,

\section{INTRODUCTION}

Cyanide is a serious environmental pollutant that is extremely toxic to several forms of life because of its inhibitory activity on a variety of key enzymes (Cipollone et al.,
2007). One major enzyme inhibited by cyanide is the cytochrome c oxidase enzyme. It blocks flow of electrons through complex IV to inhibit oxidative metabolism (Jones et al., 2003). 
Cyanide exists in form of hydrogen cyanide, sodium cyanide, potassium cyanide, calcium cyanide, or copper (1) cyanide in surface water (WHO, 2004). In plants, cyanide is usually bound to sugar molecules in the form of cyanogenic glycosides and is believed to protect the plant against herbivores. Cassava roots (also called Manihot), an important potato-like food grown in tropical countries, also contain cyanogenic glycosides (Vetter, 2000). Cassava (Manihot esculenta Crantz) is the chief source of dietary food energy for the majority of the people living in the tropics, and much of the sub-humid tropics of west and central Africa (Tsegia et al., 2002). Because of the presence of cyanoglycosides, cassava is potentially toxic to human populations that subsist on cassava-based diets with low ingestion of protein

Several antidotes for cyanide intoxication exist, including various nitric oxide donors, sodium thiosulphate, hydroxycobalamin, cobalamide and dicolbalt acetate (Gracia and Shepherd, 2004). The ideal cyanide antidote has not been discovered. Most of the known antidote are extremely toxic, defective and are used clinically. None of these clinical antidotes have been designed to serve as a remedy for cyanide toxicity in those who use cassava as their staple food. Sulphur-containing amino acids in protein have been shown to play a role in detoxification of cyanide by the donation of sulphur to the enzyme rhodanese (thiosulphate: cyanide sulphur transferase, E.C. 2.8.1.1), which detoxifies cyanide by converting it to thiocyanate. Sulphur required for the enzymatic conversion of cyanide to thiocyanate can be offered by thiosulphates or other biological compounds containing sulphane sulphur (divalent ionised sulphur bound to another sulphur atom), like polythionates, thiosulphonates, persulphides, etc. (Iciek and Wlodek, 2001).
However, in protein-deficient subjects where sulphur amino acids are low, the activity of rhodanese is reduced and $\mathrm{CN}^{-}$may conceivably be converted to cyanate $\left(\mathrm{OCN}^{-}\right)$ which is known to cause neurodegenerative disease in humans and animals. In such a situation, the introduction of an alternative source of sulphur containing nutrient to complement or replace the role of sulphurcontaining amino acids in protein will be of importance.

Phytochemicals which posses many ecological and physiological roles are widely distributed as plant constituents (Okwu et al., 2004). These include phenolic and flavonoids (Gorinstein et al., 2005). Sulphur-containing compounds contains sulphane sulphur, enhance the conversion of cyanide to thiocyanate (Iciek and Wlodek, 2001) and thus provide protection against the toxicity of cyanide. It is therefore, reasonable to suggest that the phytochemicals found in plants be used as antidote for cyanide toxicity.

Allium cepa Linn, is used as a foodstuff, condiments, flavouring, and applied in folk medicine (Banerjeea and Maulika, 2001). Botanically, the Allium species is included in the family Liliiaceae. Wild species are found across a wide range of latitudes and longitudes in Europe, Asia, North America and Africa. Onion is rich in flavonoids such as quercetin and sulphur compounds, such as allyl propyl disulphide that have perceived benefits to human health (Griffiths et al., 2002).

The studying of amino acid profiles indicated that the red onion has higher levels of sulphur-containing amino acid than the white ones. It is therefore possible that the organosulphur content of red onion confer protective effect in cyanide poisoning by its ability to provide sulphur for enzyme rhodanese. Therefore, this study aims at examining the effects of red onion on 
rhodanese activities and half-life of cyanide in the blood.

\section{MATERIALS AND METHODS}

The present study was carried out in the Department of Biochemistry, University of Ibadan, Nigeria.

\section{Plants collection and preparation of extracts}

Fresh bulbs of red onions were collected and authenticated in the Department of Botany, University of Ibadan.

\section{Extraction of plant material}

The onions were washed with distilled water and allowed to air dry for one hour. The outer covering of the onion were manually peeled off. The onion bulbs being separated were washed and extracted in the following ways:

Exactly $786 \mathrm{~g}$ of fresh onion bulbs were blended in ice and soaked in $1000 \mathrm{ml}$ of absolute methanol for 72 hours in a clean, glass container and was filtered using a sterile muslin cloth after which the extract was obtained, dried using the rotary evaporator and stored in a refrigerator until required.

A second sample of fresh onion bulbs weighing $786 \mathrm{~g}$ was blended in $200 \mathrm{ml}$ of ice and soaked in $1000 \mathrm{ml}$ of distilled water for 24 hours; the essential oil content was extracted using hydro-distiller. Hydrodistillation was carried out with the Clevenger type apparatus (Clevenger, 1928) in accordance with the European Pharmacopoeia 2005 (Özek et al., 2010). This was done by boiling the blended onion that has been soaked in water for about 12 hours, using the heating mantle from below the round bottom flask containing the socked blended onion. The boiling was carried out about 3 hours, and the volatile material produced was carried away in the steam through some tubes and then cool in the condenser. $1 \mathrm{ml}$ of hexane was passed into the channel through which the volatile oil will be collected from. The volatile oil dissolved in hexane and was then removed from the top of the hydrosol which returns back into the vessel after condensation. The extracted oil was dried over anhydrous sodium sulphate and stored at $4{ }^{\circ} \mathrm{C}$ until analysis.

\section{Experimental procedure}

Sixty male albino rats obtained from the animal colony of the veterinary Department of University of Ibadan were used for the experiments. All animals were kept at room temperatures $\left(27-30{ }^{\circ} \mathrm{C}\right)$ and had free access to drinking water and diets. The animals were acclimatized for two weeks to their environment and diet before experimentation. For the determination of rhodanese activities, the rats were grouped into six groups $(1,2,3,4,5$ and 6$)$ of six rats per group. Group 1 served as control and received $0.2 \mathrm{ml}$ of distilled water, group 2 was treated orally with $(600 \mathrm{mg} / \mathrm{kg}) \mathrm{MEAC}$, group 3 was treated orally with $7 \mathrm{mg} / \mathrm{kg}$ potassium cyanide $(\mathrm{KCN})$, group 4 was treated orally with $(300 \mathrm{mg} / \mathrm{kg}) \mathrm{MEAC}$ and $7 \mathrm{mg} / \mathrm{kg} \mathrm{KCN}$, group 5 was treated orally with $(600 \mathrm{mg} / \mathrm{kg})$ MEAC and $7 \mathrm{mg} / \mathrm{kg} \mathrm{KCN}$ and group 6 was treated orally with $(600 \mathrm{mg} / \mathrm{kg})$ thiosulphate and $7 \mathrm{mg} / \mathrm{kg} \mathrm{KCN}$ two weeks. Group 4, 5 and 6 were pre-administered with MEAC for two weeks. Animals were killed by decapitation, livers were removed immediately and rinsed in $1.15 \%$ ice-cold $\mathrm{KCl}$. The livers were homogenized in phosphate buffer ( $\mathrm{pH} 7.4)$ and centrifuged in cold centrifuged at $10,000 \mathrm{xg}$ for 10 minute to obtain the post mitochondria fractions for enzyme assay. In vitro rhodanese activity was determined using liver homogenate in the presence of MEAC, essential oil of onion and $\mathrm{Na}_{2} \mathrm{~S}_{2} \mathrm{O}_{3}$. Rhodanese activity was determined by method of Sorbo et al. (1953) as described by Aminlari et al. (1997). Half-life of KCN was determined in rats divided into four groups of six rats each, group one was given distilled water, (control), group two was given $600 \mathrm{mg} / \mathrm{kg} \mathrm{MEAC}$, 
group three was given $600 \mathrm{mg} / \mathrm{kg} \mathrm{Na} \mathrm{Na}_{2} \mathrm{~S}_{2} \mathrm{O}_{3}$ administered orally and group four was given raw onion ad libitum for two weeks. Each group was thereafter given $7 \mathrm{mg} / \mathrm{kg} \mathrm{KCN}$ intravenously. Blood was thereafter collected from the orbital sinus into heparinised tube at $0,1,2,3,5,10$ and 20 minutes. The concentration of $\mathrm{KCN}$ in each sample was determined by alkaline pictrate method modified by Ikediobi et al. (1980) and half life was estimated from the plot of concentration of $\mathrm{KCN}$ against time.

\section{Statistical analysis}

Data were presented as Mean \pm SEM, ANOVA and student t-test were used for comparison of results. Data were analysed with the use of Graphpad Prism Version 5.0 for Windows (GraphPad® Software, San Diego, CA, USA). $\mathrm{P}<0.05$ was considered significant.

\section{RESULTS}

Effects of MEAC and sodium thiosulphate on in vivo liver rhodanese activities

Expressed in figure 1 below are the results of the liver rhodanese activities. Cyanide-only-group liver rhodanese activity was significantly higher with respect to the control group $(\mathrm{P}<0.05)$. This difference was observed to increase for cyanide $+\mathrm{Na}_{2} \mathrm{~S}_{2} \mathrm{O}_{3}$ with respect to the control $(\mathrm{P}<0.001)$, however cyanide + extract and extract only liver rhodanese activity were not significantly higher with respect to the control group. Coadministration of onion extracts significantly decreased liver rhodanese activity with respect to cyanide-only-group $\quad(\mathrm{P}<0.05) \quad$ while treatment with $\mathrm{Na}_{2} \mathrm{~S}_{2} \mathrm{O}_{3}$ significantly increased it with respect to cyanide-only-group $(\mathrm{P}<0.05)$.

Effects of MEAC and sodium thiosulphate on urine thiocynate concentration

The results of the urine thiocyanate concentrations are shown below in Figure 2.
Urine thiocyanate concentration for cyanideonly-group and cyanide $+\mathrm{Na}_{2} \mathrm{~S}_{2} \mathrm{O}_{3}$ were significantly much higher when compared with the control group $(\mathrm{P}<0.001)$ while no significant difference was observed for the urine thiocyanate concentration for cyanide + extract with respect to the control group. Coadministration of onion extract significantly decreased $(\mathrm{P}<0.001)$ urine thiocyanate with respect to cyanide-only-group while treatment with $\mathrm{Na}_{2} \mathrm{~S}_{2} \mathrm{O}_{3}$ significantly increased $(\mathrm{P}<0.001)$ urine thiocyanate relatively to the cyanide-only-group.

\section{Effects of MEAC and sodium thiosulphate on in vitro liver rhodanese activities}

Figure 3 below illustrates the effect of the crude methanol extract and essential oil of red onion (at concentrations 10 folds of methanol extract) on rhodanese activity was not significantly different from each other. Figure 4 shows that rhodanese activities for $\mathrm{Na}_{2} \mathrm{~S}_{2} \mathrm{O}_{3}$ and essential oil of onion were not significantly different from each other, but were significantly different from that of the onion extract $(\mathrm{p}<0.001)$.

\section{Effects of MEAC, raw onion and sodium thiosulphate on half-life of $\mathrm{KCN}$}

Table 1 below illustrates the half-life of cyanide in the blood. The half-life of KCN in the onion extract + cyanide group was not significantly different from that of the group that did not receive any treatment before administering $\mathrm{KCN}$ intravenously, coadministration of raw onion and $\mathrm{Na}_{2} \mathrm{~S}_{2} \mathrm{O}_{3}$ however significantly decreased the half-life of $\mathrm{KCN}$ relatively to this group $(\mathrm{p}<0.01)$ and $(\mathrm{p}<0.001)$ respectively. The half-life of $\mathrm{KCN}$ in the onion extract + cyanide group was significantly higher with respect to the raw onion +cyanide $(p<0.05)$ and the $\mathrm{Na}_{2} \mathrm{~S}_{2} \mathrm{O}_{3}+$ $\mathrm{CN}(\mathrm{p}<0.01)$ groups, while the half-life $\mathrm{KCN}$ in $\mathrm{Na}_{2} \mathrm{~S}_{2} \mathrm{O}_{3}+\mathrm{CN}$ was significantly lower with respect to that of raw onion + cyanide $(\mathrm{p}<0.05)$ groups. 


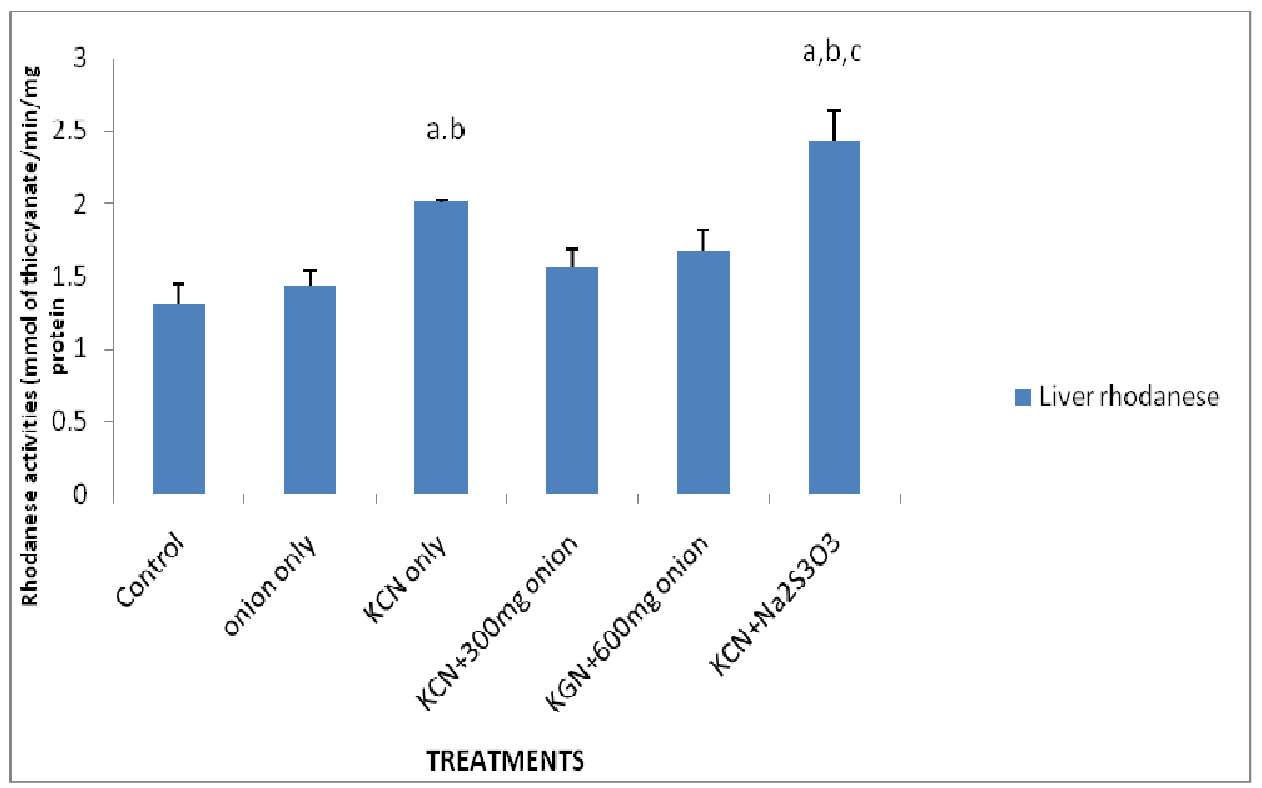

Figure 1: Liver rhodanese activities in subacute toxicity following oral administration of $7 \mathrm{mg} / \mathrm{kg}$ $\mathrm{KCN}$ in male albino rats $(\mathrm{P}<0.05)$. (a) shows a significant different between the group and the control (b) shows a significant different between the group and extract only group (C) shows a significant different between the group and $\mathrm{KCN}$ only group.

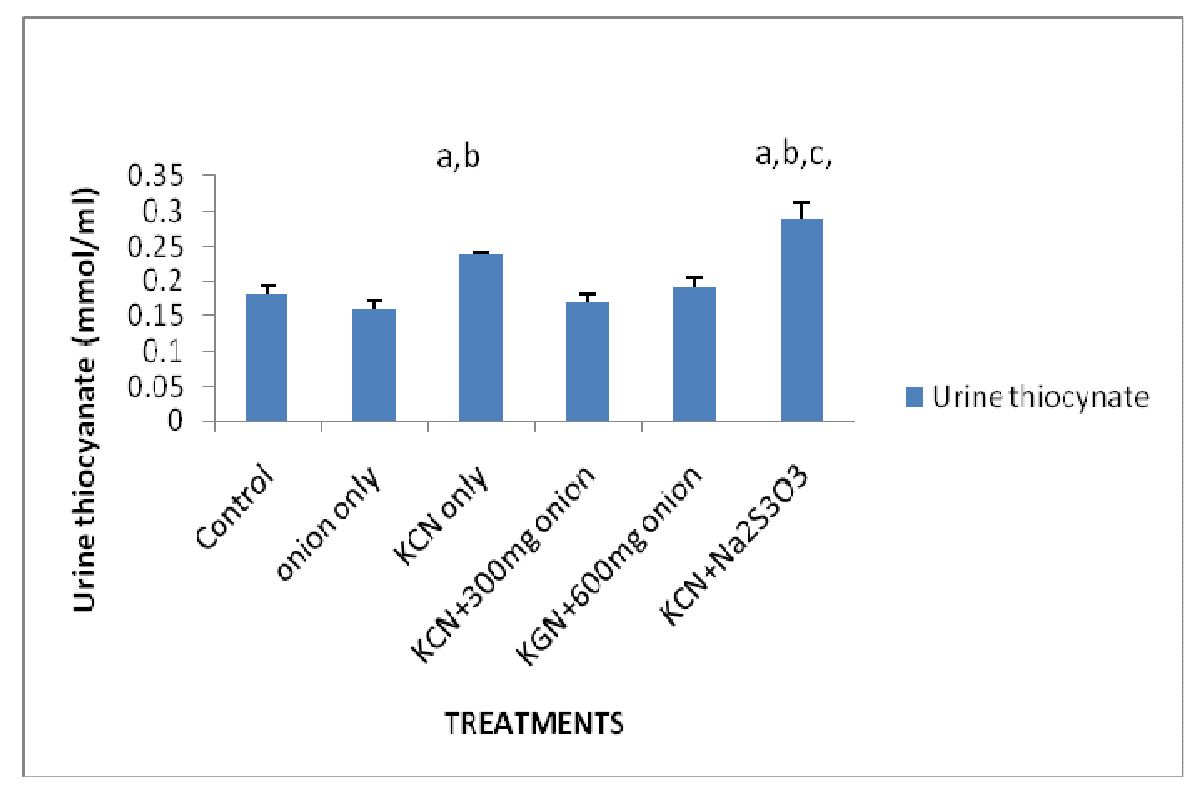

Figure 2: Urine thiocyanate concentration in subacute toxicity following oral administration of 7 $\mathrm{mg} / \mathrm{kg} \mathrm{KCN}$ in male albino rats $(\mathrm{P}<0.05)$. (a) shows a significant different between the group and the control (b) shows a significant different between the group and extract only group (C) shows a significant different between the group and $\mathrm{KCN}$ only group. 


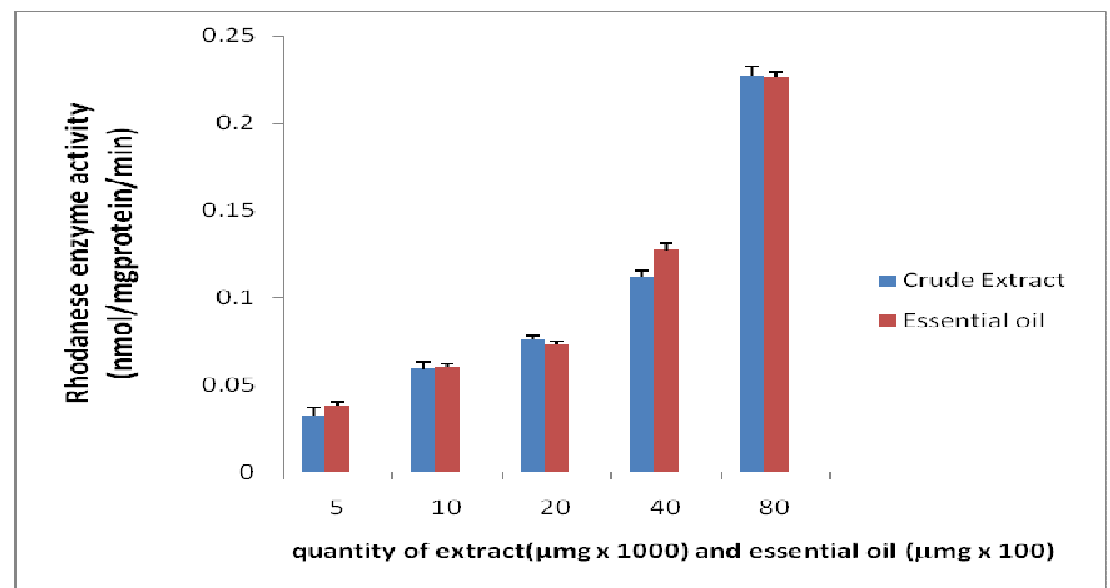

Figure 3: Effect Essential oil and crude methanol extracts of onion on rhodanase enzyme activity.

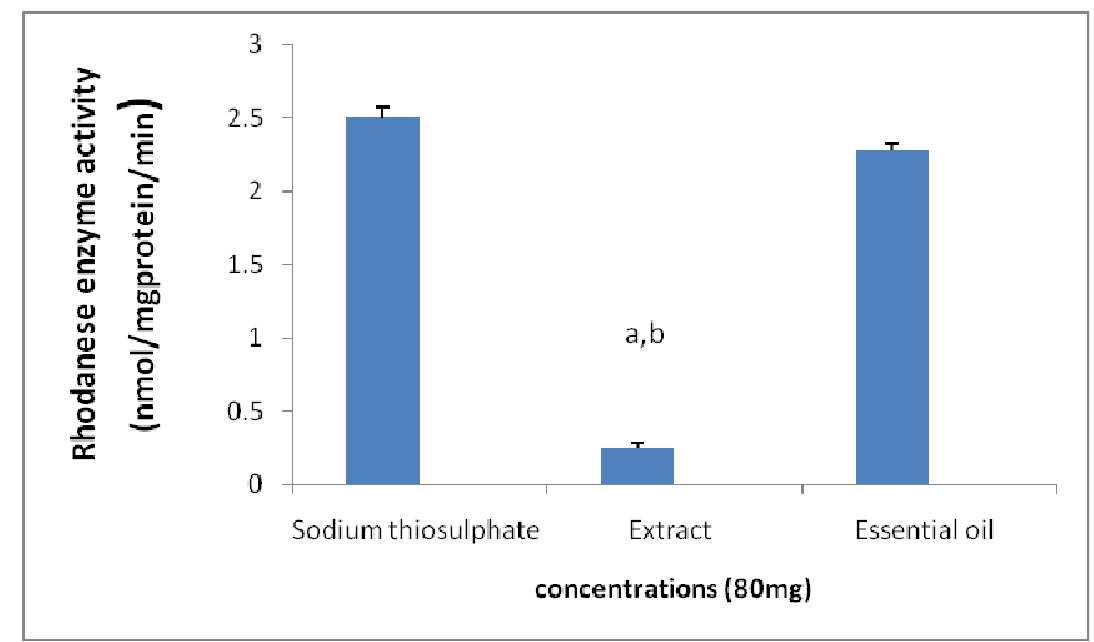

Figure 4: Effect of $\mathrm{Na}_{2} \mathrm{~S}_{2} \mathrm{O}_{3}$, Crude methanol extracts of onion and Essential oil of onion on rhodanase enzyme activity $(\mathrm{P}<0.05)$. (a) shows a significant different between the extract and $\mathrm{Na}_{2} \mathrm{~S}_{2} \mathrm{O}_{3}$ (b) shows a significant different between the extract and essential oil.

Table 1: Half life of cyanide in the blood.

\begin{tabular}{lc}
\hline Treatments & $\begin{array}{c}\text { half-life of KCN } \\
\text { (mins) }\end{array}$ \\
\hline Control(KCN only) & $9.2 \pm 0.34250$ \\
Onion Extract+ KCN & $8.1 \pm 0.35459$ \\
Raw onion $+\mathrm{KCN}$ & $5.0 \pm 0.09695(\mathrm{a}, \mathrm{b}, \mathrm{d})$ \\
$\mathrm{Na} \mathrm{S} \mathrm{O}+\mathrm{KCN}$ & $3.0 \pm 0.13111(\mathrm{a}, \mathrm{b}, \mathrm{c})$ \\
223 & \\
\hline (a) shows a significant different between the group and the control (b) shows a significant different \\
between the group and extract only group $(\mathrm{C})$ shows a significant different between the group and \\
KCN only group.
\end{tabular}




\section{DISCUSSION}

In the present study, increase in rhodanese activity was observed in the cyanide-only group relative to the control, as shown in Figure 1. This enzyme is localized in the mitochondria, and it is most abundant in the liver (Akinsiku et al., 2009). Rhodanese play a central role in cyanide detoxification (Aminari et al., 2002).

The increase in the activity of this enzyme in the presence of cyanide, may be due to the induction of the enzyme by this toxic substance and the increase observed when $\mathrm{Na}_{2} \mathrm{~S}_{2} \mathrm{O}_{3}$ was co-administered may be an additional effect produced as a result of increase availability of sulphur supplied by $\mathrm{Na}_{2} \mathrm{~S}_{2} \mathrm{O}_{3}$. Since the major mechanism for the excretion of cyanide is its enzymatic conversion by the enzyme rhodanese to thiocyanate $(\mathrm{SCN})$, increased activity of this enzyme observed in the cyanide-only and cyanide $+\mathrm{Na}_{2} \mathrm{~S}_{2} \mathrm{O}_{3}$ group indicates increased detoxification of cyanide by this pathway.

The reduction in rhodanese activity to the control value observed in animals coadministered with onion extract suggests that there may be limited supply of sulphur for rhodanese activity and that there was no induction of the enzyme by cyanide indicating a reduction in the detoxification of cyanide via rhodanese pathway in the presence of onion extract. This observation was complemented by the result shown in Figure 2 on urine thiocyanate, which follows the same trend as the rhodanese activity i.e. urine $\mathrm{SCN}^{-}$ concentration was elevated by cyanide, and much more elevated in $\mathrm{Na}_{2} \mathrm{~S}_{2} \mathrm{O}_{3}$ treated groups, however urine thiocyanate was decreased to about the control value in onion treated group.

Elevation of urine thiocyanate is an indication of the attempt by the animals to detoxify the ingested cyanide and thiocyanate remains the most important marker for cyanide exposure since it is the most stable metabolite (Haque and Bradbuny, 1999). Thus the reduced level of SCN observed in the urine of animals co-administered with onion further suggest that there was a reduction in the detoxification of cyanide via the rhodanese pathway and there may also be a reduced level of cyanide toxicity in this group, thus other pathway may be responsible for detoxification of cyanide in this animals. The elevated value of urine SCN obtained in the cyanide-only group is an index of increased toxicity and an attempt to excrete the cyanide while the highly elevated level in the $\mathrm{Na}_{2} \mathrm{~S}_{2} \mathrm{O}_{3}$ co-administered group may indicate a higher attempt to excrete the cyanide via the rhodanese pathway. Administration of thiosulphate usually in form of $\mathrm{Na}_{2} \mathrm{~S}_{2} \mathrm{O}_{3}$ has been shown to enhance rhodanese activities (Bhattacharya, 2000). The in vitro study shows (Figure 3) that there was no significant difference in the rhodanese activity in the presence of extract and in the presence of essential oil at tenfold the concentration of the extract, indicating that the essential oil is ten times as potent as the extract. The extract was also shown (Figure 4) to be less potent than the $\mathrm{Na}_{2} \mathrm{~S}_{2} \mathrm{O}_{3}$ while no significant difference was observed between $\mathrm{Na}_{2} \mathrm{~S}_{2} \mathrm{O}_{3}$ and the essential oil of onion.

Onion contains various organosulphur compounds such as dialkyl disulfides ( $\mathrm{CH}-\mathrm{S}-$ $\mathrm{S}-\mathrm{CH}_{3}, \mathrm{CH} 3-\mathrm{S}-\mathrm{S}-\mathrm{C}_{3} \mathrm{H}_{5}, \mathrm{CH}_{3}-\mathrm{S}-\mathrm{S}-\mathrm{C}_{3} \mathrm{H}_{7}$ etc), their oxides and thiols (Wu et al., 2001) and also thiosulfinate (Rose et al., 2005), etc. which may provide sulphur for the enhancement of rhodanese activity. However, these compounds are of two main types, the Salk(en)yl-cysteine sulphoxides which are the flavour precursors of onion, and the gammaglutamyl peptides which are not volatile. The typical odour of onion is developed as soon as its tissue is damaged because this damage leads to the release of volatile substances by enzymatic hydrolysis of non-volatile sulphurcontaining storage compounds i.e. the odourless S-alk(en)yl-cysteine sulphoxides, which are typical for the Allium genus. After tissue disruption and mixture of the vacuole and cytoplasmic contents, enzymatic hydrolysis cleaves these compounds to pyruvate, ammonia and a thiosulfinate (Rose et al., 2005). These volatile components of onion makes up the essential oil of onion and 
these could have been lost during the extraction process of onion and thus may result in low sulphur content of the onion extract, resulting in reduced enhancement of rhodanese activity both in the in vivo and in vitro. This view was supported by the result obtained in the study of half-life of $\mathrm{KCN}$ where onion extract only slightly decreased the half-life of $\mathrm{KCN}$ indicating that despite the cyanide load rhodanese enzyme was only slightly enhanced. However, in the presence of raw onion, the half-life of $\mathrm{KCN}$ was significantly reduced, i.e. there may be increased rhodanese activity, which may be due to the presence of both the volatile and the non-volatile organosulphur component of onion. This results in rapid clearance of $\mathrm{KCN}$.

\section{Conclusion}

Results from this study indicate that onion extract may only slightly increase rhodanese activities in vitro and in vivo and that other mechanism may be responsible for cyanide detoxification in animals coadministered with onion extract since high SCN concentration was not observed in this group. Essential oil of onion and $\mathrm{Na}_{2} \mathrm{~S}_{2} \mathrm{O}_{3}$ were able to significantly increase rhodanese activity and the major mechanism for cyanide detoxification by $\mathrm{Na}_{2} \mathrm{~S}_{2} \mathrm{O}_{3}$ may be through this pathway. The half-life of cyanide in the blood was also reduced by consumption of raw onion. Thus, onion generally and especially raw onion may reduce the toxicity of cyanide especially when the volatile sulphur compounds are intact.

\section{REFRENCES}

Akinsiku OT, Agboola FK, Kuku A, Afolayan A. 2009. Physicochemical and kinetic characteristics of rhodanese from the liver of African catfish Clarias gariepinus Burchell in Asejire Lake. Fish Physiol Biochem., DOI 10.1007/s10695-009- 9328-4.

Aminlari M, Gholami S, Vaseghi T, Azarafrooz A. 1997. Rhodanese (Thiosulfate: Cyanide Sulfurtransferase) in the Digestive tract of chicken at different stages of development. Poultry Science, 76: 318-320.

Aminlari M, Li A, Kunanithy V, Scaman CH. 2002. Rhodanese distribution in porcine (Sus scrofa) tissues. Comp. Biochem. Physiol., 132B: 309-313.

Banerjeea SK, Maulika SK. 2002. Effect of Garlic on Cardiovascular Disoder: A review. Nutritional Journal, 1(4): 1-14.

Bhattacharya R. 2000. Antidote to cyanide poisoning: present status. Indian $J$ Pharmacology, 32: 94-101.

Cipollone R, Emanuela F, Federica T, Francesco I, Paolo A, Paolo V. 2007. Involvement of Pseubdomonas aeruginosa Rhodanese in Protection from Cyanide Toxicity. Applieds and Environmental Microbiology, 73: 390-398.

Clevenger JF. 1928. Apparatus for the determination of volatile oil. J. Am. Pharm. Assoc., 17: 346.

Gorinstein S, Drzewiecki J, Leontowicz H. 2005. Comparison of the bioactive compounds and antioxidant potentials of fresh and cooked Polish, Ukranian and Israeli garlic. Journal of Agricultural and food Chemistry, 53: 2726-2732.

Gracia R, Shepherd G. 2004. Cyanide poisoning and its treatment. Pharmachotherapy, 24: 1358-1365.

Griffiths G, Trueman L, Crowther T, Thomas B. 2002. Onions: a global benefit to healthy. Phytotherapy Research., 17(7): 603-615.

Hague R, Bradbuny JH. 1999. Simple kit method for determination of thiocyanate in urine. Clin. Chem., 45 : 1459-1464.

Iciek M, Wlodek L. 2001. Biosynthesis and biological properties of compound containing highly reactive, reduced sulfane sulphur. Pol. J. Pharmacol., 53: 215-225.

Ikediobi CO, Onyia GO, Eluwa CE. 1980. A rapid and inexpensive enzymatic assay for total cyanide in cassava (Manihot escu- lanta Crantz) and 
cassava products. Agric. Biol. Chem., 44: 2803-2809.

Jones DC, Prabhakaran K, Gunasekar PG, Li L, Shou Y, Borowitz JL, Isom GE. 2003. Cyanide enhancement of dopamine-induced apoptosis in mesencephalic cells involves mitochondrial dysfunction and oxidative stress. Neurotoxicology., 24: 333342.

Okwu DW. 2004. Phytochemicals and vitamin content of indigenous species of South Eastern Nigeria. J. sustain Agric Eviron., 6: 30-37.

Özek G, Demirci F, Özek T, Tabanca N, Wedge DE, Khan SI, Hüsnü K, Baser C, Duran A, Hamzaoglu E, 2010 - Gas chromatographic - mass spectrometric analysis of volatiles obtained by four different techniques from Salvia rosifolia $\mathrm{Sm}$. and evaluation for biological activity, Journal of Chromatography., 1217: $741-748$.

Rose P, Whiteman M, Moore PK, Zhu YZ. 2005. Bioactive S-alk(en)yl cysteine sulfoxide metabolites in the genus
Allium: the chemistry of potential therapeutic agents. Nat. Prod. Rep., 22(3): 351-368.

Sorbo BH. 1953. Crystalline rhodanese. I. Purification and physicochemical examination. Acta Chem. Scand. 7: 1129-1136.

Tsegia D, Kormawa PC. 2002. Determination of urban household demand for cassava product in Kaduna, Northern Nigeria. In: conference of international research for development. Witzenhause 9-10.

Vetter J. 2000. Plant cyanogenic glycosides. Toxicon., 38(1): 11-36.

WHO (World Health Organisation). 2004. Hydrogen Cyanide and Cyanides: Human Health Aspects. Concise International Chemical Assessment Document, 61.

Wu CC, Sheen LY, Chen HW, Tsai SJ, Li CK. 2001. Effects of organosulfur compounds from garlic oil on the antioxidation system in rat liver and red blood cells, Food Chem. Toxicol., 39: 563-569. 